\title{
Berthierine in the Middle Jurassic sideritic rocks from southern Poland
}

\author{
Aleksandra KOZŁOWSKA ${ }^{1, *}$ and Anna MALISZEWSKA ${ }^{1}$ \\ 1 Polish Geological Institute - National Research Institute, Rakowiecka 4, 00-975 Warszawa, Poland,
}

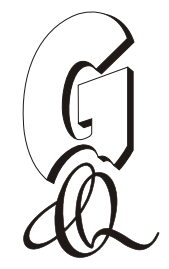

Kozłowska, A., Maliszewska, A., 2015. Berthierine in the Middle Jurassic sideritic rocks from southern Poland. Geological Quarterly, 59 (3): 551-564, doi: 10.7306/gq.1231

\begin{abstract}
A characteristic green and yellow-brown clay mineral from sideritic rocks was studied from 14 boreholes penetrating the Middle Jurassic strata of the northeastern margin of the Holy Cross Mountains and Częstochowa region, using polarizing and scanning electron microscopes, cathodoluminescence and X-ray analysis and revealing the presence of berthierine. In these sideritic rocks, berthierine occurs mainly in Lower and Middle Bathonian strata deposited in shoreface and deltaic environments of the northeastern margin of the Holy Cross Mountains, and in Upper Bajocian deposits of both areas studied. It forms the clay cement of sideritic rocks, fills voids in bioclasts and is also present in ooids. Ooids consisting of berthierine have been affected by mechanical compaction and mainly carbonate replacement. Berthierine ooids, replaced by sideroplesite, pistomesite, Fe-calcite or ankerite, and rarely by pyrite and altered by kaolinite, occur commonly. Berthierine ooids of the Bathonian sideritic rocks are typically better preserved, compared to those from the Bajocian and Aalenian. Berthierine crystallised in the eodiagenesis stage in suboxic conditions below the water-sediment interface, where iron-bearing freshwater mixed with sea water. It is chemically and structurally unstable and, during the mesodiagenetic stage at higher temperatures, could transform to chamosite by recrystallisation.
\end{abstract}

Key words: berthierine, sideritic rocks, Middle Jurassic, Holy Cross Mountains, Częstochowa region.

INTRODUCTION

Berthierine is a 1:1 layer ferrous-ferric aluminosilicate from the serpentine subgroup (Brindley and Brown, 1984). Its chemical composition is identical to that of iron-rich leptochlorite, commonly referred to as chamosite. It may also be similar to the composition of another iron aluminosilicate - odinite (Hornibrook and Longstaffe, 1996). Berthierine (like chamosite) is generally considered to be characteristic of marine deposits (Taylor and Curtis, 1995; Ryan and Hillier, 2002; Taylor et al., 2002), although it has also been reported in deposits of brackish basins (Taylor, 1990), in laterites (Fritz and Toth, 1997), and even in hydrothermal deposits (Rivas-Sanchez et al., 2006). Hypotheses concerning the genesis of berthierine are based on the source of iron. The potential sources for the iron might be: weathering (see Young and Taylor, 1989), volcanism (Dreesen, 1989; Kimberley, 1994; Sturesson et al., 2000; García-Frank et al., 2012) or hydrothermal processes (Rivas-Sanchez et al., 2006). Some authors think that berthierine is an early diagenetic mineral (e.g., Young, 1989; Taylor and Curtis, 1995), and others suggest that one model of berthierine formation does not necessarily exclude the other (e.g., Young, 1989; Reolid et al., 2008).

* Corresponding author, e-mail: aleksandra.kozlowska@pgi.gov.pl

Received: November 22, 2014; accepted: March 26, 2015; first published online: May 15, 2015
Berthierine can be considered a geothermometer. The experiments of Hornibrook and Longstaffe (1996), carried out on berthierine from Lower Cretaceous oil-bearing sands of the Clearwater Formation, Alberta, Canada, have shown that it crystallised from fresh or brackish waters at a temperature of $25-45^{\circ} \mathrm{C}$ in the early diagenetic stage. Berthierine can transform to chamosite at $70^{\circ} \mathrm{C}$, and is commonly considered its precursor (e.g., lijima and Matsumoto, 1982; Longstaffe and Ayalon, 1987). Replacement of berthierine by chamosite can thus point to $\mathrm{a}>70^{\circ} \mathrm{C}$ temperature during diagenetic alteration in sedimentary rocks (Velde, 1995; Hornibrook and Longstaffe, 1996; Meunier, 2005).

The aim of the study was to determine the phase composition of a green or yellow-brown clay mineral found in Aalenian to Bathonian sideritic, siliciclastic rocks of Poland. Customarily, it has been called chamosite. In the description of sideritic coquinas from the Łęczyca-Kłodawa region (Central Poland; Fig. 1), Turnau-Morawska (1961) suggested that the green clay mineral may be chamosite, turingite or berthierine in composition. In the early studies of these sideritic rocks (Maliszewska et al., 2005, 2006), the green mineral was provisionally called chamosite, but subsequently was identified as berthierine (Maliszewska et al., 2007). In this paper we describe the occurrence of berthierine in a range of recently studied Middle Jurassic sideritic rocks in southern Poland, and suggest its possible genesis. The results of our observations using polarizing microscope, cathodoluminescence, and XRD and SEM-EDS analyses are aimed at the question: is the occurrence of berthierine in these Middle Jurassic deposits related to a specific depositional environment and/or period of time? 


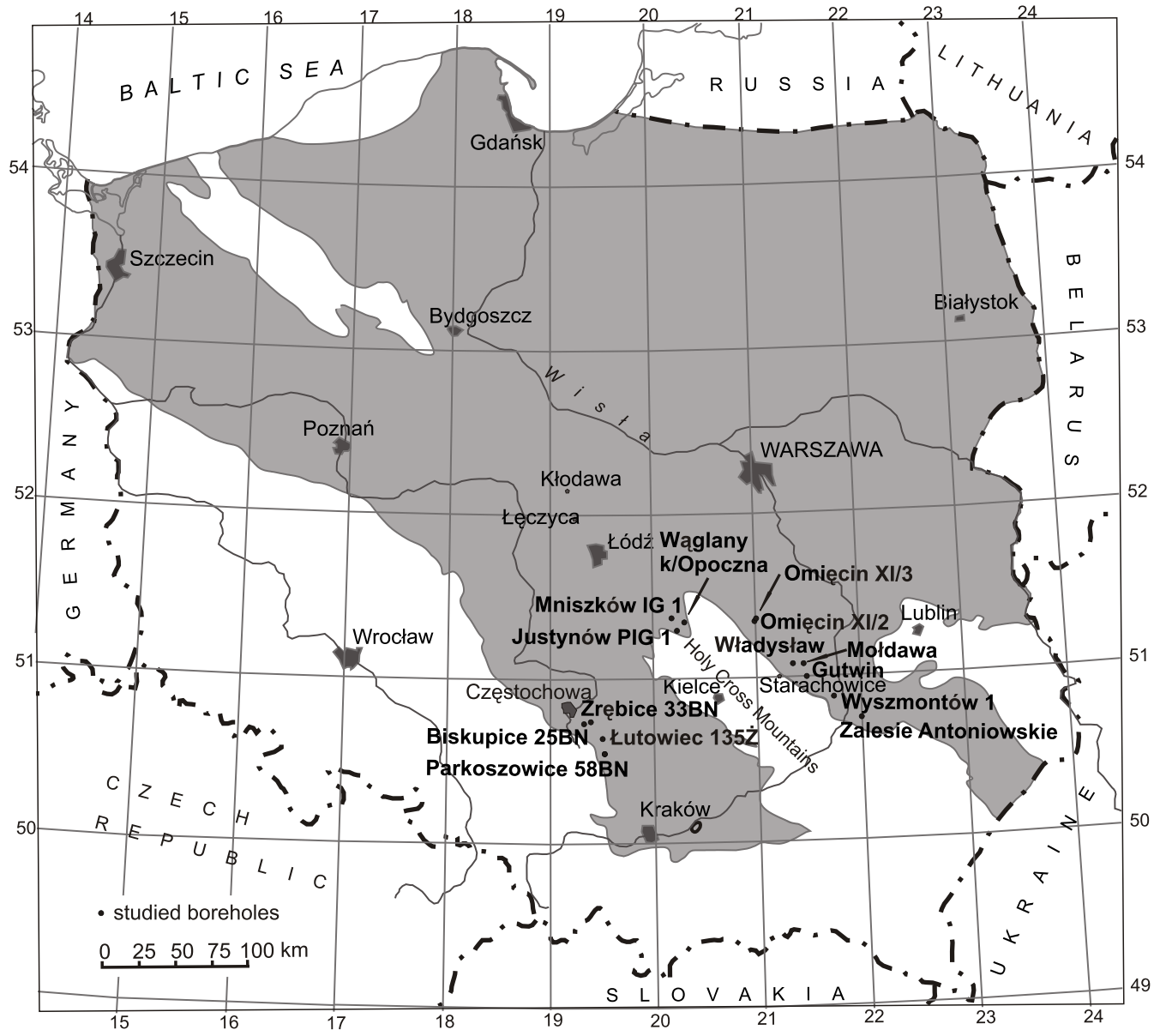

Fig. 1. Location map of the boreholes included in this study

Grey polygon - extent of the Middle Jurassic in Poland after Lott et al. (2010)

\section{GEOLOGICAL SETTING}

The study concerns Middle Jurassic rocks from the southern part of the Polish epicontinental basin (Fig. 1), which was the eastern arm of the Central European Basin System (Pieńkowski et al., 2008). The Polish Basin was surrounded from the north-east and south-west by lands that served as a source area for clastic material (Feldman-Olszewska, 1997, 1998).

Lithological-stratigraphical studies of the Jurassic succession in the southeastern margin of the Holy Cross Mountains, which began before World War II (e.g., Passendorfer, 1927, 1928; Kuźniar, 1928; Samsonowicz, 1932), provided much new data after the War, thanks to, among others, work by Kobyłecki (1948), Cieśla (1958) and Daniec (1963, 1970). The greatest thicknesses of Middle Jurassic deposits of about $800 \mathrm{~m}$ were found on the northern part of the margin. It decreases towards the south-east to approximately $180 \mathrm{~m}$ in the Wyszmontów region (Daniec, 1970). These are mainly Aalenian, Bajocian and Bathonian deposits represented by sandstones and mudstones with interbeds of claystone and sideritic iron ore (Fig. 2A). The Callovian deposits, about $20 \mathrm{~m}$ thick, are composed of carbonate and carbonate-siliceous deposits.

Lithological-stratigraphical studies of Middle Jurassic rocks in the Częstochowa region began in the late 19th century (fide
Kopik and Marcinkiewicz, 1997) and continued in the 20th century (Kopik and Marcinkiewicz, 1997). The thickness of the Middle Jurassic in the Częstochowa region is about $184 \mathrm{~m}$ in the northern area, and it decreases to approximately $85 \mathrm{~m}$ in the south (Kopik, 1998). The lithological section is represented largely by Bajocian and Bathonian sandy claystones and mudstones locally containing dark claystones with siderite, customarily referred to as ore-bearing clays (Kopik, 1998; Fig. 2B). The Callovian is only several metres thick and is represented by sandy-carbonate deposits. In the last few years, much new information on the sedimentary conditions and environments has been provided by the results of petrographic and lithological-stratigraphical studies (Gedl et. al., 2006) as well as by geochemical analyses performed by Marynowski et al. (2007), Szczepanik et al. (2007), Wierzbowski and Joachimski (2007) and Zatoń et al. (2009). The sedimentary structures in these deposits (including storm-generated structures) have been described by Leonowicz $(2012,2013)$. The mechanism of the formation of siderite and phosphate concretions in the ore-bearing clays from Gnaszyn (district of Częstochowa) with regard to sedimentary conditions and diagenetic processes was studied by Witkowska (2012).

The difference in the thickness of Middle Jurassic deposits between these two areas results from their palaeogeographic position within the epicontinental basin. It is thought that the northeastern margin of the Holy Cross Mountains occupied its 

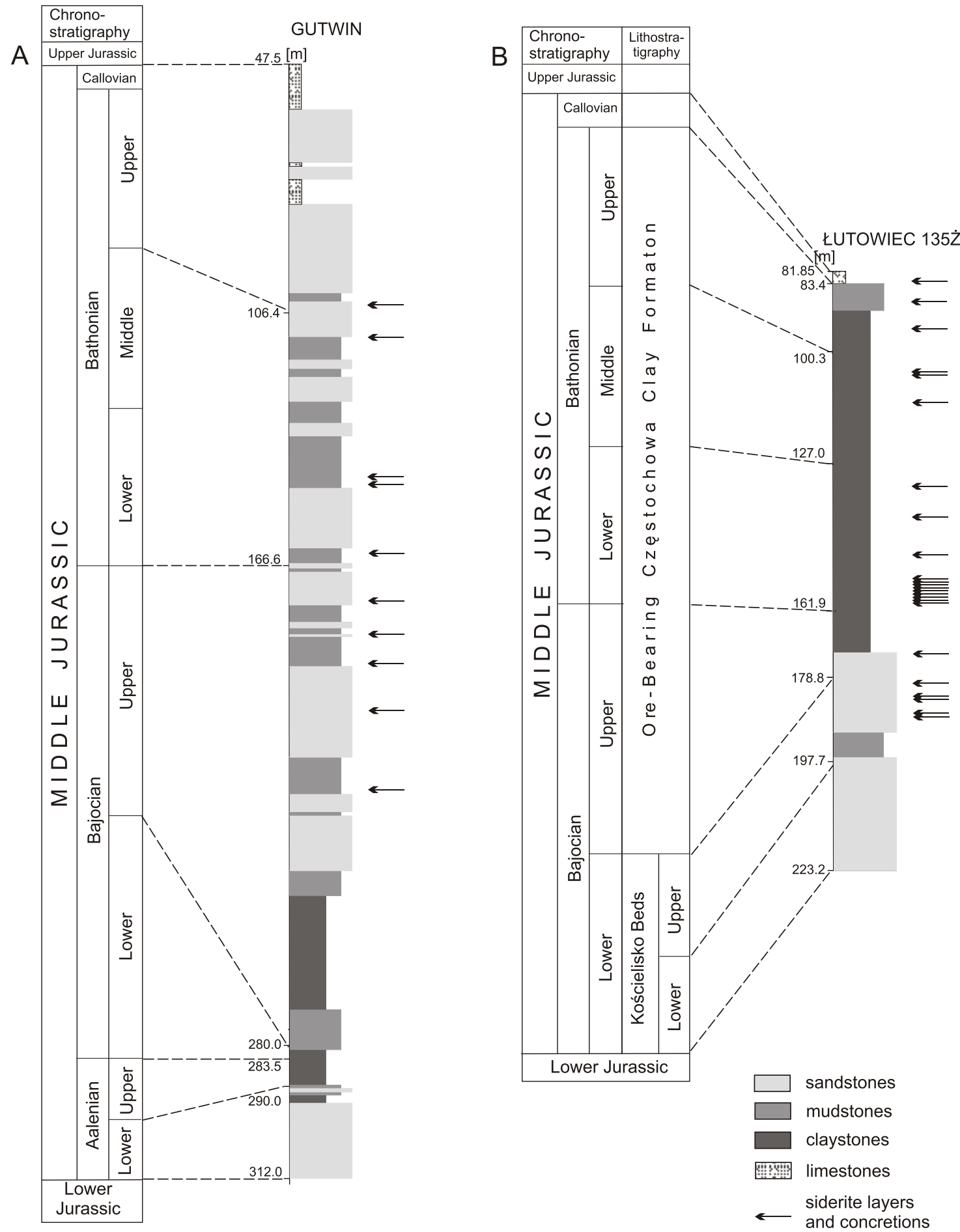

Fig. 2. Stratigraphy of the Middle Jurassic deposits from: A - northeastern margin of the Holy Cross Mountains (after Daniec, 1970) with lithological profile of the Gutwin borehole (after Feldman-Olszewska, pers. comm., 2008), and B - Częstochowa region (after Kopik, 1998) with lithological profile of the Łutowiec 135 borehole (after Feldman-Olszewska, pers. comm., 2013)

central part, whereas the Częstochowa region lay in its marginal part (Feldman-Olszewska, 1998).

Currently, we have focused on mineralogical-petrographic investigations of clayey siderites and sideritic sandstones, and partly also sideritic conglomerates and coquinas, containing a variety of coated grains and berthierine, due to their complex and interesting genesis. According to Feldman-Olszewska (pers. comm., 2013), these rocks represent various Middle Ju- rassic sedimentary environments, including: offshore, transition zone, shoreface, deltaic and estuarine environments and sporadically, carbonate ramp and Aalenian fluvial environments (Tables 1-4). Siderite layers and concretions, and sideritic sandstones are observed mainly in the Aalenian, Bajocian and Bathonian rocks of the northeastern margin of the Holy Cross Mountains and in the Bajocian and Bathonian rocks of the Częstochowa region (Fig. 2). 
Clayey siderite samples containing berthierine

\begin{tabular}{|c|c|c|c|c|c|c|c|c|c|}
\hline Area & Borehole & $\begin{array}{l}\text { Depth } \\
{[\mathrm{m}]}\end{array}$ & Age & $\begin{array}{l}\text { Berth. } \\
\text { cement }\end{array}$ & $\begin{array}{l}\text { Bert. } \\
\text { ooids }\end{array}$ & $\begin{array}{l}\text { Other } \\
\text { ooids }\end{array}$ & $\begin{array}{l}\text { Secondary } \\
\text { minerals } \\
\text { in ooids }\end{array}$ & $\begin{array}{l}\text { Percentage } \\
\text { of ooids } \\
\text { in rock } \\
\text { [vol.\%] }\end{array}$ & Method \\
\hline \multirow{17}{*}{$\begin{array}{l}\text { Northeastern margin of } \\
\text { the Holy Cross Moun- } \\
\text { tains }\end{array}$} & Gutwin & 191.1 & $\mathrm{Bj} 2$ & & & + & $\mathrm{Sd}$ & 2.0 & $\mathrm{PL}$ \\
\hline & Justynów PIG 1 & 20.3 & $\mathrm{Bj} 2(?)$ & & + & + & $\mathrm{Sd}, \mathrm{KI}$ & 1.0 & $\mathrm{PL}$ \\
\hline & \multirow{3}{*}{ Mniszków IG 1} & 958.0 & Bt1-2 & + & + & + & Ak & 1.0 & $\mathrm{PL}$ \\
\hline & & 959.5 & Bt1-2 & + & + & + & $\mathrm{Sd}$ & 0.7 & $\mathrm{PL}$ \\
\hline & & 961.0 & Bt1-2 & + & + & + & $\mathrm{Sd}$ & 1.0 & PL, X-ray \\
\hline & \multirow{2}{*}{ Mołdawa } & 274.1 & $\mathrm{Bj} 2$ & & + & + & $\mathrm{Sd}$ & 3.0 & PL, SEM \\
\hline & & 401.3 & $\mathrm{Bj} 2$ & + & + & + & $\mathrm{Sd}$ & 0.3 & $\mathrm{PL}$ \\
\hline & \multirow{3}{*}{ Omięcin XI/2 } & 36.0 & $\mathrm{Bj} 2$ & & + & + & $\mathrm{Sd}, \mathrm{KI}$ & $\operatorname{tr}$ & $\mathrm{PL}$ \\
\hline & & $67.7-68.2$ & $\mathrm{Bj} 2$ & & + & + & $\mathrm{Sd}$ & 1.7 & $\mathrm{PL}$ \\
\hline & & $116.0-116.2$ & Aa1? & & + & + & $\mathrm{Sd}, \mathrm{Pt}$ & 0.7 & $\mathrm{PL}$ \\
\hline & \multirow{2}{*}{ Omięcin XI/3 } & 132.2 & $\mathrm{Bj} 2$ & & + & + & $\mathrm{Sd}$ & 1.7 & $\mathrm{PL}$ \\
\hline & & 184.4 & $\mathrm{Bj} 2$ & & + & + & $\mathrm{Sd}$ & $\operatorname{tr}$ & $\mathrm{PL}$ \\
\hline & \multirow{3}{*}{$\begin{array}{l}\text { Waglany } \\
\text { k/Opoczna }\end{array}$} & 395.2 & Bt1-2 & & + & + & $\mathrm{Sd}, \mathrm{Ca}$ & 18.0 & PL, SEM \\
\hline & & 412.4 & Bt1-2 & & + & + & $\mathrm{Sd}, \mathrm{Ca}$ & 1.7 & PL, SEM \\
\hline & & 597.2 & Aa1 & & + & + & $\mathrm{Pt}, \mathrm{KI}$ & 9.3 & PL, SEM \\
\hline & \multirow{2}{*}{ Wyszmontów 1} & 80.5 & Bt1-2 & & + & + & $\mathrm{Sd}$ & 11.0 & PL, SEM \\
\hline & & 129.3 & $\mathrm{Bj} 2$ & & + & + & $\mathrm{Ca}$ & 1.0 & $\mathrm{PL}$ \\
\hline \multirow{11}{*}{ Częstochowa region } & \multirow{4}{*}{$\begin{array}{l}\text { Biskupice } \\
\text { 25BN }\end{array}$} & 58.1 & Bt3 & + & + & + & $\mathrm{Sd}, \mathrm{Ca}, \mathrm{Py}$ & 6.0 & $\mathrm{PL}$ \\
\hline & & 132.4 & $\mathrm{Bt1}$ & & + & + & $\mathrm{Sd}$ & 1.0 & $\mathrm{PL}$ \\
\hline & & 190.1 & $\mathrm{Bj} 2$ & + & + & + & $\mathrm{Sd}, \mathrm{KI}$ & 1.0 & PL, SEM \\
\hline & & 190.6 & $\mathrm{Bj} 2$ & + & + & + & $\mathrm{Sd}, \mathrm{KI}$ & 2.0 & $\mathrm{PL}$ \\
\hline & Łutowiec 135 & 178.9 & $\mathrm{Bj} 1$ & + & + & + & $\mathrm{Sd}$ & 2.0 & PL, SEM \\
\hline & \multirow{4}{*}{$\begin{array}{l}\text { Parkoszowice } \\
\text { 58BN }\end{array}$} & 34.5 & $\mathrm{Bt3}$ & & + & + & $\mathrm{Ca}, \mathrm{Sd}$ & 3.3 & PL, SEM \\
\hline & & 101.0 & $\mathrm{Bj} 2$ & & + & + & $\mathrm{Ca}, \mathrm{Ak}$ & 15.0 & PL, SEM, CL \\
\hline & & 101.2 & $\mathrm{Bj} 2$ & & + & + & $\mathrm{Sd}, \mathrm{Ca}, \mathrm{Ak}$ & 25.0 & $\mathrm{PL}$ \\
\hline & & 104.1 & $\mathrm{Bj} 2$ & & + & + & $\mathrm{Sd}$ & 15.0 & PL, SEM \\
\hline & \multirow{2}{*}{ Zrębice 33BN } & 297.8 & $\mathrm{Bt} 1$ & & + & + & $\mathrm{Sd}, \mathrm{Ca}, \mathrm{Py}$ & 2.7 & $\mathrm{PL}, \mathrm{CL}$ \\
\hline & & 353.4 & $\mathrm{Bj} 2$ & + & & & & & $\mathrm{PL}$ \\
\hline
\end{tabular}

Aa1 - Lower Aalenian, Cl - Callovian, Aa2 - Upper Aalenian, Bj1 - Lower Bajocian, Bj2 - Upper Bajocian, Bt1 - Lower Bathonian, Bt2 - Middle Bathonian, Bt3 - Upper Bathonian; Ak - ankerite, $\mathrm{Ca}$ - calcite, $\mathrm{Kl}$ - kaolinite, Sd - sideroplesite, $\mathrm{Pt}$ - pistomesite, $\mathrm{Py}$ - pyrite; tr - trace; $\mathrm{PL}$ - polarizing microscope; SEM - scanning electron microscope; CL - cathodoluminescence; X-ray - X-ray diffraction analysis; ${ }^{*}-$ no berthierine, chlorite present

\begin{tabular}{|l|c|c|c|c|c|c|}
\hline \multicolumn{7}{|c|}{ Environments } \\
\hline offshore & transition zone & shoreface & deltaic & estuary & carbonate ramp & fluvial \\
\hline
\end{tabular}

\section{MATERIAL AND METHODS}

The rock samples studied originated from 14 boreholes drilled along the northeastern margin of the Holy Cross Mountains and in the Częstochowa region (Fig. 1) in the period 1955-1989. The boreholes were drilled for iron ore mining in both areas, where intensive mining development dates from the 17 th century and came to an end in the 1980s.

Rock samples were collected from all sideritic interlayers and concretions that were found in the boreholes investigated. A total number of 276 thin sections was made, which were studied using a polarizing microscope Nikon Eclipse LV 100 Pol. Detailed analysis was performed on 82 thin sections of sideritic rocks in which berthierine was identified (Tables 1-4). The de- scription of coated grains is based on a scheme used by Turnau-Morawska (1961) and the definition of Flügel (2010), according, with some modifications, to the classification of coated grains by Kearsley (1989). Thin sections were stained with the Evamy's solution to identify carbonate minerals. Seven samples containing calcite or ankerite were subjected to cathodoluminescence analysis using the so-called "cold cathode", CITL MK5 type from Cambridge Image Technology Ltd.

The mineralogical composition of the $<2 \mathrm{~m}$ fraction of the sediment (clay minerals) from 10 samples (Table 5) was determined by X-ray diffraction analysis using a Philips X'Pert PW 3020 diffractometer (Cu K $\alpha$ radiation and semiconductor detector). Samples were crushed and ground to obtain particles of less than $0.063 \mathrm{~mm}$ in size. The analysis was performed on oriented air-dried samples, which were subsequently glycolized 
Table 2

Sideritic sandstone samples containing berthierine

\begin{tabular}{|c|c|c|c|c|c|c|c|c|c|}
\hline Area & Borehole & $\begin{array}{l}\text { Depth } \\
\text { [m] }\end{array}$ & Age & $\begin{array}{l}\text { Berth. } \\
\text { cement }\end{array}$ & $\begin{array}{l}\text { Berth. } \\
\text { ooids }\end{array}$ & $\begin{array}{l}\text { Other } \\
\text { ooids }\end{array}$ & $\begin{array}{l}\text { Secondary } \\
\text { minerals } \\
\text { in ooids }\end{array}$ & $\begin{array}{l}\text { Percentage } \\
\text { of ooids } \\
\text { in rock } \\
\text { [vol.\%] }\end{array}$ & Method \\
\hline \multirow{35}{*}{$\begin{array}{l}\text { Northeastern margin } \\
\text { of the Holy Cross } \\
\text { Mountains }\end{array}$} & \multirow{3}{*}{ Gutwin } & 124.2 & Bt1-2 & + & + & & & 4.4 & PL, X-ray, SEM \\
\hline & & 167.6 & $\mathrm{Bj} 2$ & + & + & & & 1.3 & $\mathrm{PL}$ \\
\hline & & 191.5 & $\mathrm{Bj} 2$ & & + & + & Sd & 3.0 & $\mathrm{PL}$ \\
\hline & Mniszków IG 1 & 962.0 & Bt1-2 & + & + & & & $\operatorname{tr}$ & PL \\
\hline & \multirow{18}{*}{ Mołdawa } & 73.2 & $\mathrm{Bt} 3-\mathrm{Cl}$ & + & + & & & 3.0 & PL \\
\hline & & 94.9 & Bt2-3 & + & + & & & tr. & $\mathrm{PL}$ \\
\hline & & 109.0 & Bt1-2 & + & + & & & 2.3 & $\mathrm{PL}$ \\
\hline & & 113.4 & Bt1-2 & + & + & + & $\mathrm{Ak}, \mathrm{Py}$ & 1.7 & $\mathrm{PL}$ \\
\hline & & 123.6 & Bt1-2 & + & + & & & 10.7 & PL \\
\hline & & 168.7 & Bt1-2 & + & + & & $\mathrm{Ca}$ & tr & $\mathrm{PL}$ \\
\hline & & 208.0 & Bt1-2 & + & + & + & $\mathrm{Sd}, \mathrm{Ca}$ & 1.7 & PL, X-ray \\
\hline & & 216.7 & Bt1-2 & + & + & + & $\mathrm{Sd}$ & 0.7 & PL \\
\hline & & 229.6 & Bt1-2 & + & & & & & $\mathrm{PL}$ \\
\hline & & 250.75 & Bt1-2 & + & + & + & $\mathrm{Sd}, \mathrm{Ak}$ & 44.7 & $\mathrm{PL}, \mathrm{CL}$ \\
\hline & & 281.5 & Bj2 & + & + & + & $\mathrm{Ca}, \mathrm{Sd}, \mathrm{KI}$ & 3.3 & $\mathrm{PL}$ \\
\hline & & 308.0 & $\mathrm{Bj} 2$ & & + & + & $\mathrm{Sd}$ & 17.0 & $\mathrm{PL}$ \\
\hline & & 313.4 & $\mathrm{Bj} 2$ & & + & + & $\mathrm{Sd}, \mathrm{Pt}, \mathrm{KI}$ & 5.4 & $\mathrm{PL}$ \\
\hline & & 321.8 & $\mathrm{Bj} 2$ & + & + & + & Sd, Pt & 7.3 & $\mathrm{PL}$ \\
\hline & & 347.0 & $\mathrm{Bj} 2$ & & + & + & $\mathrm{Ak}, \mathrm{KI}$ & 6.7 & $\mathrm{PL}, \mathrm{CL}$ \\
\hline & & 352.0 & $\mathrm{Bj} 2$ & & + & + & $\mathrm{Ak}$ & 0.3 & $\mathrm{PL}$ \\
\hline & & 354.3 & $\mathrm{Bj} 2$ & & & + & $\mathrm{Sd}$ & 0.7 & PL, SEM \\
\hline & & 387.7 & $\mathrm{Bj} 2$ & + & + & + & Ak & 55.7 & $\mathrm{PL}$ \\
\hline & \multirow{6}{*}{ Omięcin XI/2 } & 77.9-78.9 & $\mathrm{Bj} 2$ & & + & + & $\mathrm{Sd}$ & 0.7 & $\mathrm{PL}$ \\
\hline & & 104.4 & Bt1-2 & * & & & & & PL, X-ray \\
\hline & & 105.4 & Bt1-2 & + & + & + & $\mathrm{Ca}$ & 1.3 & $\mathrm{PL}$ \\
\hline & & 172.9 & $\mathrm{Bj} 2$ & + & + & + & $\mathrm{Ca}, \mathrm{Ak}$ & 3.0 & PL, X-ray, SEM \\
\hline & & 202.9 & $\mathrm{Bj} 1$ & + & + & + & $\mathrm{Ca}, \mathrm{Kl}, \mathrm{Ak}$ & 0.3 & PL \\
\hline & & 225.0 & Aa1? & & + & + & $\mathrm{Sd}$ & 4.3 & $\mathrm{PL}$ \\
\hline & \multirow{2}{*}{$\begin{array}{l}\text { Wąglany } \\
\text { k/Opoczna }\end{array}$} & 482.7 & $\mathrm{Bj2}$ & & + & + & $\mathrm{Py}, \mathrm{KI}, \mathrm{Sd}$ & 4.0 & $\mathrm{PL}$ \\
\hline & & 643.8 & Aa1 & 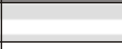 & + & + & $\mathrm{Pt}$ & 5.3 & PL, SEM \\
\hline & \multirow{2}{*}{ Władysław } & 166.8 & Bt1-2 & + & + & & & $\operatorname{tr}$ & PL \\
\hline & & 200.5 & Bt1-2 & + & + & + & $\mathrm{Ca}$ & 3.7 & PL, SEM \\
\hline & Wyszmontów 1 & 91.6 & $\mathrm{Bj} 2$ & & + & + & $\mathrm{Ca}$ & 16.7 & $\mathrm{PL}$ \\
\hline & \multirow{2}{*}{$\begin{array}{c}\text { Zalesie } \\
\text { Antoniowskie }\end{array}$} & 278.5 & Aa2 & & + & + & $\mathrm{KI}, \mathrm{Py}$ & 24.3 & PL, X-ray \\
\hline & & 279.3 & Aa2 & & + & + & $\mathrm{KI}, \mathrm{Py}$ & 16.0 & $\mathrm{PL}$ \\
\hline Area & Borehole & $\begin{array}{l}\text { Depth } \\
\text { [m] }\end{array}$ & Age & $\begin{array}{l}\text { Berth. } \\
\text { cement }\end{array}$ & $\begin{array}{l}\text { Berth. } \\
\text { ooids }\end{array}$ & $\begin{array}{l}\text { Other } \\
\text { ooids }\end{array}$ & $\begin{array}{l}\text { Secondary } \\
\text { minerals } \\
\text { in ooids }\end{array}$ & $\begin{array}{l}\text { Percentage } \\
\text { of ooids } \\
\text { in rock } \\
\text { [vol. \%] }\end{array}$ & Method \\
\hline \multirow{12}{*}{$\begin{array}{l}\text { Częstochowa } \\
\text { region }\end{array}$} & \multirow{4}{*}{ Biskupice 25BN } & 190.1 & $\mathrm{Bj} 2$ & + & + & + & $\mathrm{Sd}, \mathrm{KI}$ & tr & PL, SEM \\
\hline & & 190.6 & $\mathrm{Bj} 2$ & + & + & + & $\mathrm{Sd}$ & 2.0 & $\mathrm{PL}$ \\
\hline & & 192.4 & $\mathrm{Bj} 2$ & + & + & & & 3.0 & PL, X-ray \\
\hline & & 199.1 & $\mathrm{Bj} 2$ & + & + & & & 0.7 & $\mathrm{PL}$ \\
\hline & \multirow{3}{*}{ Łutowiec 135} & 172.6 & $\mathrm{Bj} 2$ & & + & + & $\mathrm{Sd}, \mathrm{KI}, \mathrm{Ak}$ & 3.0 & PL, SEM, CL \\
\hline & & 180.6 & $\mathrm{Bj} 1$ & + & + & & & 6.3 & PL, X-ray, SEM \\
\hline & & 183.5 & $\mathrm{Bj} 1$ & + & + & & & 1.7 & $\mathrm{Pl}$ \\
\hline & \multirow{5}{*}{ Zrębice 33BN } & 301.2 & Bt1 & + & + & + & $\mathrm{Ca}$ & 1.0 & PL \\
\hline & & 307.7 & Bt1 & + & & & & & $\mathrm{PL}$ \\
\hline & & 353.95 & $\mathrm{Bj} 2$ & + & + & + & $\mathrm{KI}, \mathrm{Sd}$ & 2.0 & $\mathrm{PL}$ \\
\hline & & 355.0 & $\mathrm{Bj} 2$ & + & + & & & 1.0 & PL, X-ray \\
\hline & & 372.7 & $\mathrm{Bj} 2$ & + & + & + & $\mathrm{Sd}$ & 0.3 & PL, SEM \\
\hline
\end{tabular}

For explanations see Table 1 
Sideritic coquina samples containing berthierine

\begin{tabular}{|c|c|c|c|c|c|c|c|c|c|}
\hline Area & Borehole & $\begin{array}{l}\text { Depth } \\
\text { [m] }\end{array}$ & Age & $\begin{array}{l}\text { Berth. } \\
\text { cement }\end{array}$ & $\begin{array}{l}\text { Berth. } \\
\text { ooids }\end{array}$ & $\begin{array}{l}\text { Other } \\
\text { ooids }\end{array}$ & $\begin{array}{c}\text { Secondary } \\
\text { minerals } \\
\text { in ooids }\end{array}$ & $\begin{array}{l}\text { Percentage } \\
\text { of ooids } \\
\text { in rock } \\
\text { [vol. \%] }\end{array}$ & Method \\
\hline \multirow{2}{*}{$\begin{array}{l}\text { Northeastern margin of the } \\
\text { Holy Cross Mountains }\end{array}$} & \multirow{2}{*}{ Władysław } & 157.5 & Bt1-2 & + & + & & $\mathrm{Sd}, \mathrm{Ca}$ & 2.3 & $\mathrm{PL}, \mathrm{CL}$ \\
\hline & & 194.0 & Bt1-2 & + & + & + & $\mathrm{Ca}$ & 2.3 & $\mathrm{PL}, \mathrm{X}$-ray, $\mathrm{CL}$ \\
\hline
\end{tabular}

For explanations see Table 1

Sideritic conglomerate samples containing berthierine

\begin{tabular}{|c|c|c|c|c|c|c|c|c|c|}
\hline Area & Borehole & $\begin{array}{l}\text { Depth } \\
{[\mathrm{m}]}\end{array}$ & Age & $\begin{array}{l}\text { Berth. } \\
\text { cement }\end{array}$ & $\begin{array}{l}\text { Berth. } \\
\text { ooids }\end{array}$ & $\begin{array}{l}\text { Other } \\
\text { ooids }\end{array}$ & $\begin{array}{l}\text { Secondary } \\
\text { minerals in } \\
\text { ooids }\end{array}$ & $\begin{array}{l}\text { Percentage } \\
\text { of ooids } \\
\text { in rock } \\
\text { [vol.\%] }\end{array}$ & Method \\
\hline \multirow{5}{*}{$\begin{array}{l}\text { Northeastern margin of the } \\
\text { Holy Cross Mountains }\end{array}$} & Justynów PIG 1 & 26.0 & BJ2 (?) & + & + & + & $\mathrm{Ca}$ & $\operatorname{tr}$ & $\mathrm{PL}$ \\
\hline & \multirow{3}{*}{ Mołdawa } & 153.1 & Bt1-2 & + & + & + & $\mathrm{Ca}$ & 1.0 & $\mathrm{PL}$ \\
\hline & & 303.9 & $\mathrm{Bj} 2$ & + & + & + & $\mathrm{Ca}, \mathrm{Sd}$ & 4.0 & $\mathrm{PL}$ \\
\hline & & 326.6 & $\mathrm{Bj} 2$ & & + & + & $\mathrm{Ca}, \mathrm{KI}$ & 18.7 & $\mathrm{PL}$ \\
\hline & Omięcin XI/3 & 109.1 & Bt1-2 & + & + & + & $\mathrm{Ca}$ & 2.0 & $\mathrm{PL}$ \\
\hline
\end{tabular}

For explanations see Table 1

Results of X-ray diffraction analysis of selected samples

\begin{tabular}{|c|c|c|c|c|c|c|c|c|}
\hline Area & \multirow{2}{*}{ Borehole } & \multirow{2}{*}{$\begin{array}{l}\text { Depth } \\
\text { [m] }\end{array}$} & \multirow{2}{*}{ Age } & \multirow{2}{*}{ Rock type } & \multicolumn{4}{|c|}{ Clay fraction } \\
\hline \multirow{8}{*}{$\begin{array}{l}\text { Northeastern margin of the } \\
\text { Holy Cross Mountains }\end{array}$} & & & & & Berthierine & Kaolinite & Illite & Chlorite \\
\hline & Gutwin & 124.2 & Bt1-2 & sideritic sandstone & + & + & - & - \\
\hline & Mniszków IG 1 & 961.0 & Bt1-2 & clayey sideritic & + & + & + & - \\
\hline & Mołdawa & 208.0 & Bt1-2 & sideritic sandstone & + & + & - & - \\
\hline & \multirow{2}{*}{ Omięcin XI/3 } & 104.4 & Bt1-2 & sideritic sandstone & - & + & + & + \\
\hline & & 172.9 & Bj2 & sideritic sandstone & + & + & - & - \\
\hline & Władysław & 194.0 & Bt1-2 & sideritic coquina & + & - & - & - \\
\hline & Zalesie Antoniowskie & 278.5 & $\mathrm{Aa2}$ & sideritic sandstone & - & + & - & - \\
\hline \multirow{3}{*}{ Częstochowa region } & Biskupice 25BN & 192.4 & $\mathrm{Bj} 2$ & sideritic sandstone & + & - & - & - \\
\hline & Łutowiec 135 & 180.6 & $B j 1$ & sideritic sandstone & + & - & + & - \\
\hline & Zrębice 33B & 355.0 & $\mathrm{Bj} 2$ & sideritic sandstone & + & - & - & - \\
\hline
\end{tabular}

For explanations see Table 1

and heated at $550^{\circ} \mathrm{C}$. They were studied in angular range $1-26^{\circ} 2 \theta$ (Figs. 3 and 4 ).

The chemical composition of clay minerals was determined on four carbon-covered thin sections using a LEO scanning electron microscope (SEM) with energy dispersive X-ray analyzer (Table 6). Additionally, the chemical composition of carbonate minerals was determined on 15 samples. Back-scattered electron images (BSE) were also made.

\section{RESULTS}

Berthierine was identified in clayey siderites, sideritic sandstones and conglomerates, and also in two coquina samples.
This mineral mainly comprises ooids but also occurs as the cement and fills voids in bioclasts (Fig. 5). Siderite, which is the main component of the sideritic rocks, is represented mostly by its Mg-rich variety - sideroplesite, rarely pistomesite; pure siderite is also present (Kozłowska et al., 2008, 2011, 2013).

\section{CLAYEY SIDERITES (TABLE 1)}

The main component of the clayey siderites is sideroplesite in the form of micrite and microspar, or occasionally as spar. Clay pelite, silt-sized and sand-sized quartz grains, together with Fe-calcite and ankerite occur in varying amounts. The percentage of clay pelite, locally impregnated by organic matter or 


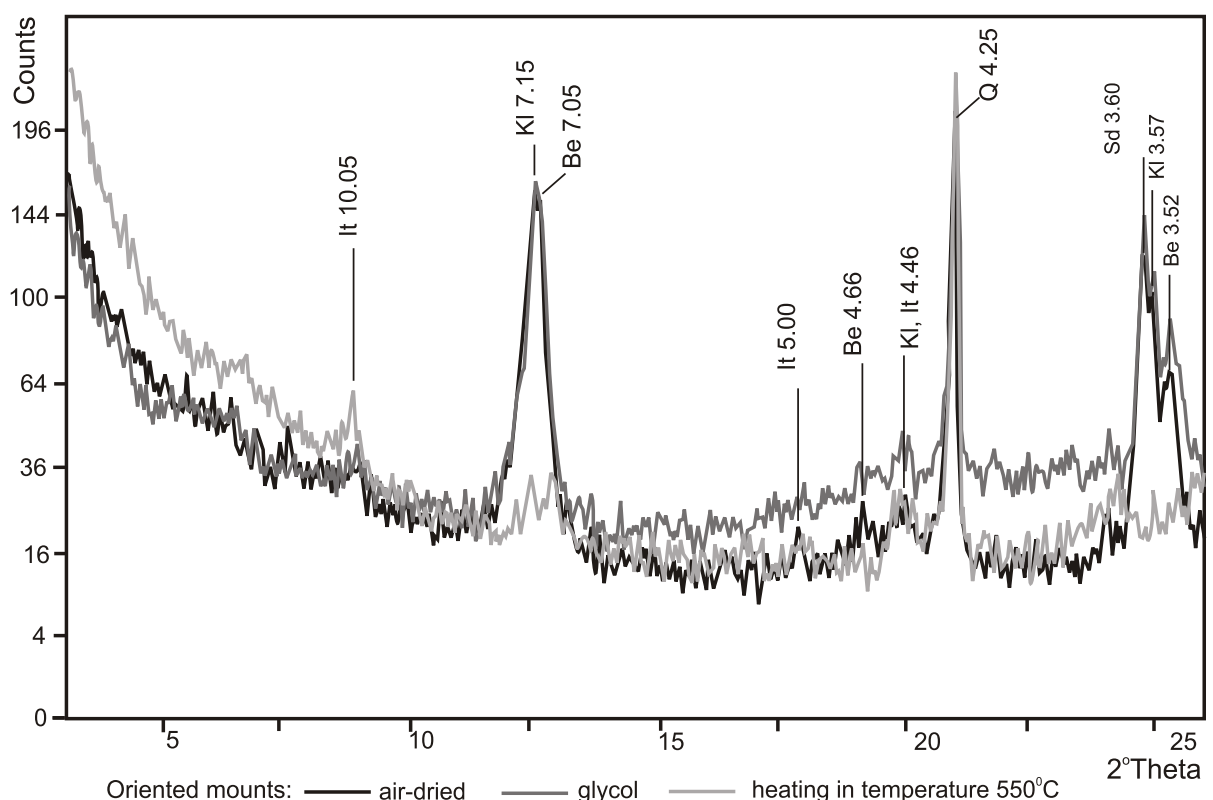

$\mathrm{Be}$ - berthierine, It - illite, $\mathrm{KI}$ - kaolinite, $\mathrm{Sd}$ - siderite, $\mathrm{Q}$ - quartz

Fig. 3. XRD diagram of clay fraction in clayey siderite

Mniszków IG 1 borehole, depth $961.0 \mathrm{~m}$

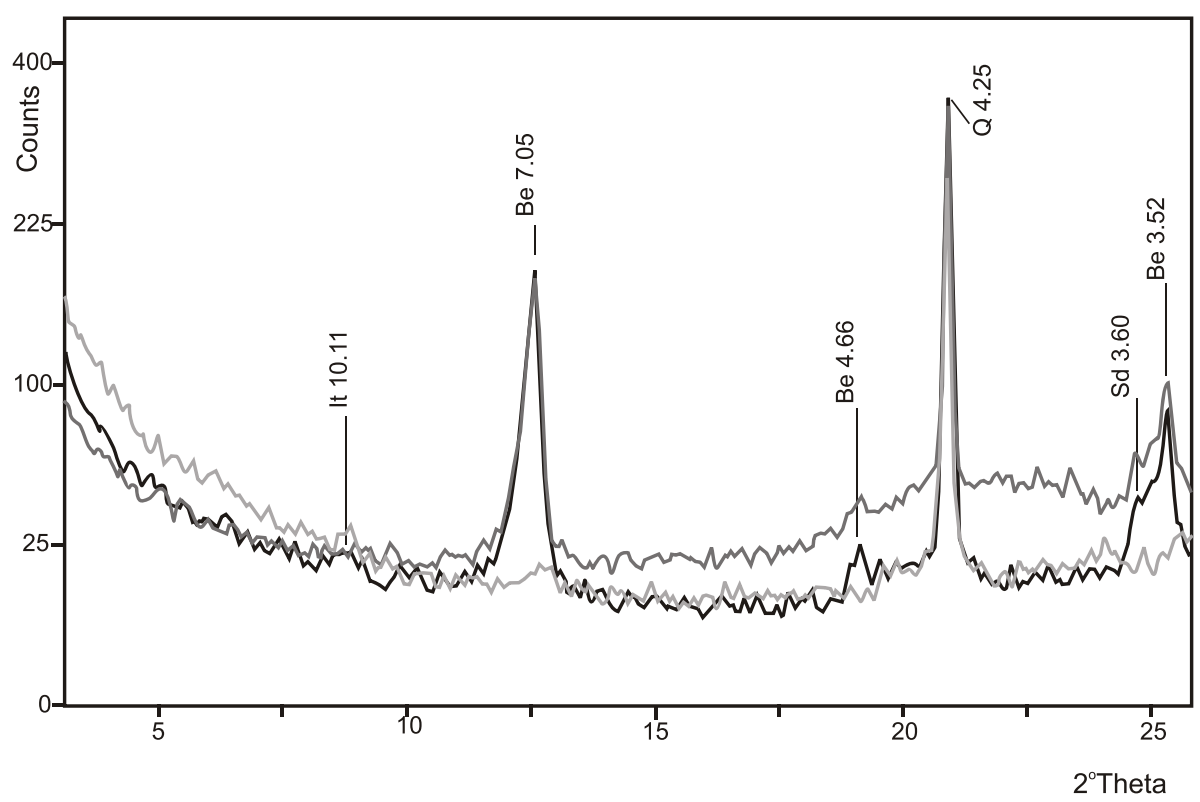

Fig. 4. XRD diagram of clay fraction in sideritic sandstone

Łutowiec 135 borehole, depth 180.6 m; for other explanations see Figure 3

iron hydroxides, varies from 0 to $30 \%$. Clay minerals occurring in the form of colourless, very fine, low-birefringent flakes are represented mainly by kaolinite. Green and yellow aggregates of clay minerals have been recognized as berthierine and illite. The microscopic observations have been confirmed by X-ray studies (Table 5 and Fig. 3). On the XRD pattern, berthierine is a mineral characterized by an intense reflection at $7.05 \AA$ and two reflections of lesser intensity at 4.66 and $3.52 \AA$ (Stoch, 1974). In contrast, chlorites are recognised by the basal reflection at $14.0-14.3 \AA$. Low-iron varieties are characterized by the basal reflections of the first five orders with strong or medium intensity. High-iron chlorites are characterized by the presence of strong reflections at 7.09 and $3.53 \AA$, and relatively weak reflec-

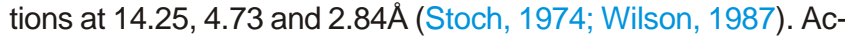
cessory components include feldspar grains, mica flakes, zircon, pyrite, hematite and organic matter. Calcitic, locally pyritized faunal fragments (bivalves, brachiopods, gastropods, echinoderms and foraminifers) are common. Iron-rich, carbonate and clay-rich ooids were observed in some of the samples; their size varies from 0.2 to $2.5 \mathrm{~mm}$. Berthierine ooids in clayey 
Results of analyses of berthierine in ooids

\begin{tabular}{|c|c|c|c|c|c|c|c|c|c|c|c|}
\hline $\begin{array}{l}\text { Borehole } \\
\text { Rock type }\end{array}$ & $\begin{array}{l}\text { Depth } \\
\text { [m] }\end{array}$ & Age & $\begin{array}{l}\mathrm{SiO}_{2} \\
{[\mathrm{wt} . \%]}\end{array}$ & $\begin{array}{l}\mathrm{Al}_{2} \mathrm{O}_{3} \\
{[\mathrm{wt} . \%]}\end{array}$ & $\begin{array}{c}\mathrm{FeO} \\
{[w t . \%]}\end{array}$ & $\begin{array}{l}\mathrm{MnO} \\
{[\mathrm{wt} . \%]}\end{array}$ & $\begin{array}{l}\mathrm{CaO} \\
{[\mathrm{wt} . \%]}\end{array}$ & $\begin{array}{l}\mathrm{MgO} \\
{[\mathrm{wt} . \%]}\end{array}$ & $\begin{array}{l}\mathrm{K}_{2} \mathrm{O} \\
{[\mathrm{wt} . \%]}\end{array}$ & $\begin{array}{l}\mathrm{P}_{2} \mathrm{O}_{5} \\
{[w t . \%]}\end{array}$ & $\begin{array}{c}\text { Total } \\
\text { [wt.\%] }\end{array}$ \\
\hline Gutwin & 124.0 & Bt1-2 & 33.52 & 21.70 & 25.59 & 0.44 & 1.13 & 0.00 & 0.00 & 0.00 & 89.08 \\
\hline Sideritic sandstone & & & 35.41 & 20.80 & 26.87 & 0.32 & 1.08 & 5.44 & 0.00 & 0.00 & 89.91 \\
\hline Omięcin XI/3 & 172.9 & $\mathrm{Bj} 2$ & 31.42 & 28.40 & 26.01 & 0.00 & 0.55 & 5.40 & 0.00 & 0.00 & 91.76 \\
\hline Sideritic sandstone & & & 34.28 & 25.79 & 29.29 & 0.05 & 0.08 & 3.52 & 0.00 & 0.00 & 93.00 \\
\hline Biskupice 25BN & 190.1 & $\mathrm{Bj} 2$ & 26.93 & 23.16 & 33.48 & 0.00 & 0.00 & 3.07 & 0.29 & 0.00 & 86.92 \\
\hline Clayey siderite & & & 27.14 & 22.96 & 36.04 & 0.00 & 0.00 & 2.68 & 0.08 & 0.00 & 88.91 \\
\hline $\begin{array}{l}\text { Łutowiec } 135 \\
\text { Sideritic sandstone }\end{array}$ & 180.6 & $\mathrm{Bj} 1$ & 20.78 & 21.64 & 38.05 & 0.00 & 0.39 & 1.14 & 0.27 & 1.36 & 83.63 \\
\hline
\end{tabular}

For explanations see Table 1

siderites are rare (Fig. 5A). A sample from the Biskupice 25BN borehole was analysed for the chemical composition of berthierine in an ooid (Table 6). Ooids, formed as a result of replacement of berthierine ooids by carbonate minerals (sideroplesite, pistomesite, Fe-calcite and ankerite; Fig. 5B, C) and pyrite or altered to kaolinite, are more frequent. In the same sample, the degree of berthierine replacement by secondary minerals varied. The greatest percentage of berthierine ooids (11\%) was observed in a sample from the Wyszmontów 1 borehole (depth $80.5 \mathrm{~m}$ ), and the greatest proportion of ooids composed of the carbonate minerals sideroplesite, calcite and ankerite $(25 \%)$ was found in a sample from the Parkoszowice 58BN borehole (depth $101.2 \mathrm{~m}$ ) (Table 1).

\section{SIDERITIC SANDSTONES (TABLE 2)}

The sideritic sandstones are represented by fine- to medium-grained quartz arenites. Detrital material is dominated by quartz grains. Feldspars, micas and zircon occur in minor percentages. Shell fragments of bivalves, echinoderms, gastropods and foraminifers and ooids were observed in variable amounts. The bioclasts are commonly composed of calcite, occasionally of ankerite, siderite and kaolinite. Locally, the voids in bioclasts are filled with a green mineral, probably berthierine. The ooids are oval, rarely spheroidal grains, 0.1 to $1.2 \mathrm{~mm}$ in size. They are composed of a green or yellow-brown mineral. The XRD analysis revealed this mineral to be berthierine (Table 5). The nuclei of the ooids are commonly represented by quartz grains or small bioclasts (Fig. 5D). Some of the ooids seem to be devoid of foreign objects, which is probably due to the cross-section being cut obliquely in relation to the centre. The cortex of the berthierine ooids reveals a subtle concentric structure (Fig. 5D-F). Some of the ooids are flattened as a result of mechanical compaction (Fig. 5E). The ooids were frequently subjected to carbonatization; berthierine has been partly or completely replaced by either Fe-calcite (Fig. 5F), ankerite (Fig. $5 \mathrm{E})$, sideroplesite or pistomesite. Additionally, the berthierine ooids have also been replaced by pyrite and altered to kaolinite (Fig. 5G). Ooids are relatively frequent in the sideritic sandstones. The greatest percentage of berthierine ooids (16.7\%) was found in a sample from the Wyszmontów 1 borehole (depth $91.6 \mathrm{~m})$, and of ooids replaced by carbonates - ankerite (55.7\% of rock volume) - in the Mołdawa borehole (depth $387.7 \mathrm{~m}$ ) (Table 2). The sandstones are cemented by micritic and microsparitic sideroplesite, sparitic sideroplesite, pistomesite, anker- ite, Fe-calcite and clay minerals (Fig. $5 \mathrm{H}$ ). As regards clay minerals, the XRD analysis confirmed the presence of kaolinite, berthierine, illite (Table 5 and Fig. 4) and occasional chlorites. In addition to illite and kaolinite, chlorites were identified in the cement of sandstone from the Omięcin $\mathrm{XI} / 3$ borehole, depth $104.4 \mathrm{~m}$, which does not contain berthierine (Table 5). Chlorites provide a strong reflection peak at $7.15 \AA$ and two peaks of lesser intensity at 14.29 and $3.52 \AA$. This may suggest that the mineral called "chlorite" is a ferruginous variety. Based on observations made using a polarizing microscope, the yellowbrown mineral that forms the cement was preliminarily identified as berthierine.

\section{SIDERITIC COQUINA (TABLE 3)}

The two samples of sideritic coquina (bioclasts $-20 \%$ of rock volume) from the Władysław borehole are composed mainly of silt- or sand-sized quartz grains and bioclasts - fragments of echinoderms, bivalves, brachiopods, gastropods, bryozoans and serpulid tubes. Berthierine ooids, feldspars and rock clasts occur in smaller amounts. Some of the berthierine ooids have been replaced to a variable degree by Fe-calcite and sideroplesite (20-80\%). The cement is composed of sideroplesite, Fe-calcite and clay minerals - berthierine. XRD analysis of the clay fraction revealed the presence of berthierine (Table 5).

\section{SIDERITIC CONGLOMERATE (TABLE 4)}

The three samples of sideritic conglomerate from the Mołdawa borehole are of polymictic paraconglomerate (see Jaworowski, 1987). Psephite clasts are represented by quartz grains and rock fragments of calcite- or berthierine-cemented sandstones, quartzites and carbonates. Among bioclasts, the most common are echinoderms, bivalves, gastropods and corals. The matrix has a composition of sandstone with ooids cemented by berthierine, microsparitic sideroplesite and Fe-calcite.

The sample from the Justynów PIG 1 borehole is a polymictic paraconglomerate. Psephite clasts are represented by fragments of quartzite and carbonate, and ankerite- or berthierine-cemented sandstone and polycrystalline quartz. The matrix has a composition of sideritic sandstone with some fragments of echinoderms, bivalves and foraminifers, as well as berhierine ooids replaced by Fe-calcite cemented mainly by micrite siderolpesite, locally by berthierine. 

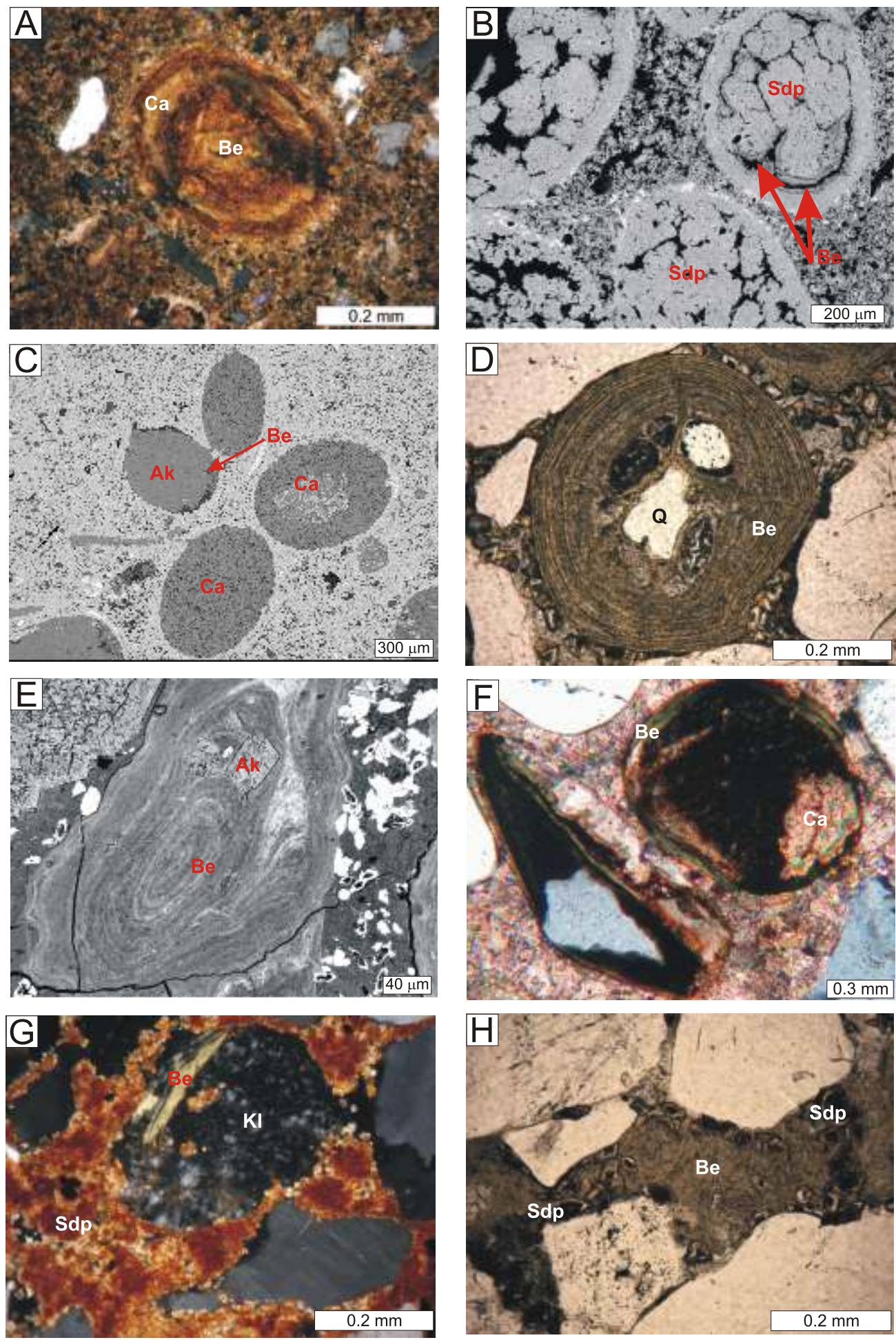

Fig. 5. Photographs in polarizing microscope (PL) and scanning electron microscope (BSE)

A - berthierine ooid $(\mathrm{Be})$ partly replaced by Fe-calcite $(\mathrm{Ca})$ in clayey siderite (Parkoszowice 58BN borehole, depth $34.5 \mathrm{~m}, \mathrm{PL}$ - crossed polars); $\mathbf{B}$ - sideroplesite ooids (Sdp) in clayey siderite composed of sideroplesite microsparite; berthierine $(\mathrm{Be})$ relicts (Waglany k/Opoczna borehole, depth $395.4 \mathrm{~m}$, BSE image); C - ooids composed of Fe-calcite $(\mathrm{Ca})$ and ankerite $(\mathrm{Ak})$ in clayey siderite composed of sideroplesite micrite; berthierine (Be) relicts (Parkoszowice 58BN borehole, depth $101.0 \mathrm{~m}$, BSE image); $\mathbf{D}$ - berthierine ooid (Be) with concentric lamellae and quartz $(\mathrm{Q})$ nucleus in sideritic sandstone (Łutowiec 135 borehole, depth $180.6 \mathrm{~m}, \mathrm{PL}$ - one polar); $\mathbf{E}$ - flattened berthierine ooid (Be) with concentric lamellae, partly replaced by ankerite (Ak), in sideritic sandstone (Gutwin borehole, depth $124.0 \mathrm{~m}$, BSE image); $\mathbf{F}$ - berthierine ooid (Be) partly replaced by Fe-calcite $(\mathrm{Ca})$ in sideritic sandstone (Omięcin XI/3 borehole, depth $105.4 \mathrm{~m}, \mathrm{PL}$ - crossed polars); $\mathrm{G}$ - berthierine ooid $(\mathrm{Be})$ altered to kaolinite $(\mathrm{KI})$ in sideritic sandstone composed of sideroplesite micrite (Sdp) (Zrebice 33BN borehole, depth $353.95 \mathrm{~m}, \mathrm{PL}$ - crossed polars); $\mathbf{H}$ - sideritic sandstone with berthierine (Be) and sideroplesite (Sdp) cements (Łutowiec 135 borehole, depth $180.6 \mathrm{~m}, \mathrm{PL}$ - one polar) 
The sample from the Omięcin $\mathrm{XI} / 3$ is an oligomictic paraconglomerate. Psephite clasts are represented by fragments of calcite-siderite-cemented sandstones with a few fragments of bivalves and echinoderms, and berthierine ooids cemented by fine-crystalline sideroplesite and berthierine occasionally.

\section{INTERPRETATION AND DISCUSSION}

\section{OCCURRENCE OF BERTHIERINE}

Berthierine forms the clay cement of these sideritic rocks, fills voids in bioclasts, and occurs in ooids. Large intergranular spaces filled with the berthierine cement indicate its precipitation in the sediment before or at the beginning of mechanical compaction. The filling of voids in bioclasts by berthierine shows its early precipitation. The berthierine ooids observed in the Middle Jurassic rocks of the region studied belong to class B, according to the Kearsley (1989) classification. Subclass B2 is the most common and is represented by pure berthierine ooids with well-defined concentric cortical laminae which are often well-preserved (Fig. 5D). These coated grains formed directly by eodiagenetic crystallisation from solution or gel. There is also some evidence that concentric berthierine (and phosphate) ooids developed by in situ accretion in iron-rich muds in quiet-water lagoons and then were incorporated into sandy sediments during offshore storms (Knox, 1970; Pufahl and Grimm, 2003). Some berthierine and kaolinite ooids belong to subclass B4. They are clearly soft and the effects of compactional deformation are visible in the form of squashed grains (Fig. 5E). The genesis of these ooids is diagenetic, and kaolinite is a secondary mineral in them. Ooids from subclass B5 have also been observed. They represent compact berthierine ooids with bioclast cores, but of berthierine composition. According to Kearsley (1989), they probably formed as a result of diagenetic replacement of primary aragonite ooids.

It is observed that berthierine was commonly replaced by siderite and sideroplesite which, in turn, were replaced by Fe-calcite and ankerite. Berthierine in ooids was also replaced by carbonate minerals and pyrite, and altered to kaolinite. According to the Kearsley (1989) classification, the carbonate ooids belong to class $\mathrm{C}$ and subclasses from $\mathrm{C} 1$ to $\mathrm{C} 4$. They represent secondary siderite and calcite ooids produced by the replacement of earlier phyllosilicate ooids. Replacement processes locally lead to complete obliteration of the original concentric structure (Fig. 5C). This is caused by the circulation of $\mathrm{Fe}-, \mathrm{Ca}-$ and $\mathrm{Mg}$-rich pore fluids in the rock volume during the late stage of diagenetic processes.

In the area studied, berthierine has been found in marine strata deposited in shoreface to offshore and deltaic environments, in a period spanning the Early Bajocian through the Late Bathonian (Feldman-Olszewska, pers. comm., 2013; Tables $1-4)$. There is no consensus about the climatic conditions in Middle Jurassic times in Poland. Dudek (2012) suggested a cool climate with mechanical weathering dominant; however, Gedl and Ziaja (2012) proposed a warm climate during Bathonian deposition in the Częstochowa region. According to Hallam (2001), the Middle Jurassic climate in Europe was similar to the recent one. Odin (1990) suggested that berthierine forms primarily in tropical to subtropical seas. In the Częstochowa region, the Bathonian fine siliciclastic deposits accumulated in a marine environment in the offshore zone, most likely below the storm wave base (Leonowicz, 2012), and in suboxic conditions (Leonowicz, 2013). The occurrence of berthierine in both marine and deltaic deposits of the study area, in places of mixing of freshwater and sea water, may indicate sea level changes. The degree of salinity of the basin is a crucial factor in berthierine crystallisation.

Bathonian (mainly Lower and Middle Bathonian) sideritic rocks with berthierine occur predominantly along the northeastern margin of the Holy Cross Mountains (Tables 1-4). They are represented by sideritic sandstones deposited in shoreface and deltaic environments, and rarely by clayey siderites of the shoreface environment. Two samples are represented by sideritic conglomerates deposited in the shoreface environment, and two sideritic coquina samples are related to deltaic and carbonate ramp deposits. The ooids in these rocks are included in ooid subclasses B2, locally B5 and B4. Deltaic ooids are commonly better preserved, compared to those deposited in the shoreface environment. It is observed that berthierine is partly replaced in ooids by Fe-calcite and sideroplesite, and rarely by ankerite and pyrite.

Berthierine from the Bajocian sideritic rocks has been found in both study areas (Tables 1, 2 and 4). Most of the samples are Late Bajocian in age and are represented by sideritic sandstones, locally conglomerates deposited in the shoreface, locally offshore and deltaic environments, and by clayey siderites deposited in the offshore, transition and shoreface zones. The most common ooids are of type $\mathrm{C}$, represented by partly or completely replaced ooids, likely of subclass B2. Berthierine in these ooids has been replaced by sideroplesite, pistomesite, Fe-calcite and ankerite, and pyrite. Secondary kaolinite is also present in these ooids. Three sideritic sandstone samples and one clayey siderite sample are Early Bajocian in age. They represent deltaic deposits in which ooids of subclasses B2 and B4 are well-preserved in the Częstochowa region. Whereas, in the northeastern margin of the Holy Cross Mountains, berthierine in ooids is occasionally completely replaced mainly by Fe-calcite and, to a lesser extent, by ankerite, and altered to kaolinite.

In a few rock samples of Aalenian deposits, from the northeastern margin of the Holy Cross Mountains only, secondary ooids with traces of berthierine have been found (Tables 1 and 2). The Upper Aalenian is represented by sideritic sandstone containing about 20 vol. $\%$ ooids and deposited in the offshore environment. The ooids are partly filled with pyrite and included in subclass B2. X-ray analysis provided no evidence for the presence of berthierine. In addition to siderite and pyrite, kaolinite has also been identified (Table 6). It is likely that kaolinite is a secondary mineral after berthierine. The Lower Aalenian fluvial and estuarine sideritic sandstone, as well as the clayey siderite deposited in the shoreface zone, contain minerals the original material of which, probably berthierine, has been completely replaced by sideroplesite and pistomesite.

In the sideritic rocks, berthierine occurs primarily in those deposited in the shoreface and deltaic environments of the Early and Middle Bathonian along the northeastern margin of the Holy Cross Mountains, and of the Late Bajocian of both areas. In the rocks examined, berthierine ooids are better preserved in the Bathonian deposits, compared with those in the Bajocian and Aalenian. Diagenetic processes of replacement and alteration of berthierine developed most intensely in clayey siderites. In the Bathonian of the northeastern margin of the Holy Cross Mountains, marine deposits of predominantly shoreface environment contain ooids in which berthierine is replaced by Fe-calcite and sideroplesite, and rarely by ankerite. Berthierine ooids from the Bathonian deltaic deposits are commonly well-preserved. The Upper Bajocian shoreface deposits contain predominantly secondary ooids in which berthierine has locally been completely replaced by sideroplesite, pistomesite, Fe-calcite, ankerite and pyrite, and altered to kaolinite. These processes were more poorly developed in the Częstochowa re- 
gion compared to the northeastern margin of the Holy Cross Mountains. Similar variability in the effects of diagenetic processes, in both the study areas, has been noticed in the Lower Bajocian deltaic deposits. In the northeastern margin of the Holy Cross Mountains, the Aalenian sideritic rocks of various environments contain only secondary ooids composed of kaolinite, pyrite, sideroplesite and pistomesite.

\section{ORIGIN OF BERTHIERINE}

The occurrence of berthierine in the rocks examined shows that the mineral was formed during the early stage of diagenesis - the eodiagenesis stage (diagenetic stages after Choquette and Pray, 1970)

During eodiagenesis, the essential factor was a circulation of pore water containing land-derived organic matter and iron compounds. Hornibrook and Longstaffe (1996) have shown that berthierine crystallised at a temperature of $25-45^{\circ} \mathrm{C}$. According to Worden and Morad (2003) and Wilson (2013) the formation of berthierine took place in tropical, offshore and deltaic environments where iron-bearing freshwater mixed with sea water. In marine sediments with a significant freshwater influx, berthierine forms close to the sediment surface but requires isolation from oxidized water to present re-oxidation (Odin and Matter, 1981). It crystallises using reduced iron $\left(\mathrm{Fe}^{2+}\right)$ in the methanogenic zone under conditions of very low sedimentation rates (Odin, 1988). According to Taylor (1998), berthierine crystallised within the suboxic diagenetic zone in marine conditions. García-Frank et al. (2012) also suggested precipitation of berthierine in suboxic conditions in the earliest stages of diagenesis, probably below the active sediment-water interface. It seems that the most probable source of iron for berthierine in the study area is river water carrying material originating from weathering processes on land. A volcanic-origin of iron should be excluded because there was no volcanic activity in adjacent areas in Jurassic times. Odin (1988) has described three facies of Fe-clay mineralisation, from which two - verdin and oolitic ironstone-could have existed in the Middle Jurassic in the area studied. Both of these facies are associated with points of local fluvial discharge into the marine environment. Due to contact between freshwater and sea water, the salinity of the former increases causing the flocculation of iron and its deposition in an amorphous, highly reactive state (Ehrenberg, 1993). Berthierine forms by diagenetic recrystallisation of odinite or precursor minerals similar to it (Odin et al., 1988). The formation of berthierine requires reducing conditions in which the activity of sulphides and bicarbonate is low (Taylor, 1990; Fritz and Toth, 1997; Sheldon and Retallack, 2002). Additionally, Fritz and Toth (1997) report that berthierine precipitation is associated with low activity of silica in solution, because otherwise kaolinite would form. Locally, the amount of silica must have increased in some ooids and berthierine was transformed to kaolinite (Fig. 5G). Kaolinite forms in an acidic environment (Osborne et al., 1994) where a significant role is played by meteoric waters, slightly acidic due to dissolution of $\mathrm{CO}_{2}$ and organic acids (Giles and de Boer, 1990). During the change from suboxic to anoxic conditions, berthierine is replaced by pyrite in the zone of sulphate reduction. Under conditions of freshwater inflow, methanogenic bacteria transform organic matter to produce $\mathrm{CO}_{2}$ and $\mathrm{CH}_{4}$ (Claypool and Kaplan, 1974). In the oxygen-deficient environment, in sediments rich in reactive minerals containing iron, and at a low concentration of dissolved sulphates, berthierine is replaced by precipitating siderite (Browne and Kingston, 1993; Morad, 1998). In the rocks examined, this is siderite enriched with magnesium - predominantly sideroplesite (Kozłowska et al., 2008, 2011, 2013; Witkowska, 2012). In the eodiagenesis stage, berthierine ooids underwent deformation, especially flattening, as a result of mechanical compaction (Fig. 5E). The effects of mechanical compaction are best manifested in sandstones. They include close packing of detrital material, reduction in primary porosity, fracturing of grains, deformation of clay-mud laminae and, locally, bending of mica flakes.

In the subsequent diagenetic stage - mesodiagenesis berthierine ooids were replaced to a variable extent by carbonate minerals that penetrated into the grains from the outside (Fig. 5F). These minerals were crystallising around the ooid and, gradually growing into its central point, were replacing berthierine. Due to an active circulation of fluids, the following precipitation sequence occurred: sideroplesite, pistomesite, Fe-calcite and ankerite. The crystallising sideroplesite and pistomesite are characterised by a high magnesium content compared with early diagenetic sideroplesite, and they are often rhombohedral in shape (Kozłowska et al., 2008, 2011, 2013). Studies of fluid inclusions in sideroplesite and pistomesite crystals indicate that their crystallisation temperature was $>60^{\circ} \mathrm{C}$ (Kozłowska, 2014). Next, Fe-calcite and ankerite formed, filling the space between siderite, sideroplesite and pistomesite crystals, showing that they crystallised later.

Early diagenetic berthierine is chemically and structurally unstable. With increasing temperature and depth of burial, this mineral transformed to chlorite. The transformation process was gradual and mixed-layering chlorite/serpentine records its intermediate stage (Wilson, 2013). According to Jahren and Aagaard (1989), berthierine is transformed to chamosite as a result of crystallisation at a temperature of about $70^{\circ} \mathrm{C}$. The transformation of berthierine to chamosite is a dissolution-precipitation reaction in closed or semi-closed systems (Aagaard et al., 2000). Berthierine may have been the precursor of ferruginous chlorites found in some samples. The cement of sandstone from a sample taken at a depth of $104.4 \mathrm{~m}$ in the Omięcin $\mathrm{XI} / 3$ borehole (Table 2 ) is composed of a yellow-brown mineral. Based on microscopic observations, the mineral was identified as berthierine, however, X-ray analysis revealed that it was chlorite. This may suggest that, during their diagenetic history, the rocks could attain temperatures $>60^{\circ} \mathrm{C}$. This is also confirmed by the results of analysis of fluid inclusions in some sideroplesite and pistomesite crystals, indicating the temperatures of their crystallisation was $62-137^{\circ} \mathrm{C}$.

\section{BERTHIERINE AND OTHER CLAY MINERALS}

The results of XRD (Table 5) and point chemical analyses (Table 6) of clay minerals from sideritic rocks in both study areas confirm the presence of berthierine. In the samples analysed, the green and yellow-brown mineral that mostly comprises ooids, but which also occurs in the cement and fills voids in bioclasts, has been identified as berthierine. In some samples, berthierine is accompanied by kaolinite or illite.

XRD studies of the Lower and Middle Bathonian rocks along the northeastern margin of the Holy Cross Mountains reveal the presence in the clay fraction of berthierine, kaolinite, illite, with minor chlorites. Single samples of Upper Bajocian rock contain berthierine and kaolinite while Aalenian rocks contain kaolinite. It seems that, in this area, kaolinite predominates over the other clay minerals. Analysis of selected rock samples from the Częstochowa region, containing the clay fraction, has revealed the presence of berthierine (Upper Bajocian) and berthierine and illite (Lower Bajocian). 
Study of the Middle and Upper Bathonian deposits rich in clay minerals in the Częstochowa area shows that illite prevails over kaolinite and chlorites (Dudek, 2012). Variability in the composition of clay minerals within deposits of different ages in the Middle Jurassic may suggest changes in the climatic conditions of the area studied.

The chemical analysis of berthierine indicates a regional differentiation. Berthierine from the northeastern margin of the Holy Cross Mountains typically shows a higher content of $\mathrm{SiO}_{2}$, $\mathrm{CaO}$ and $\mathrm{MgO}$ and a lower content of $\mathrm{FeO}$ as compared with berthierine from the Częstochowa region. This may be indicative of a greater supply of iron from land to the Middle Jurassic (Bajocian) basin in the Częstochowa area compared to the northeastern margin of the Holy Cross Mountains.

The results of analyses that identified berthierine among clay minerals of these Middle Jurassic sideritic rocks are consistent with the results of studies by Maliszewska et al. (2007) from the Polish Lowlands. They confirm the presence of berthierine in the Middle Jurassic deposits, and not only of chamosite, as was previously commonly thought. The smaller amount of kaolinite in the Częstochowa ores compared to the Starachowice ores (Fig. 1) was reported by Jaskólski (1928). Recently published papers report the occurrence of both illite and kaolinite from the deposits of the Middle and Upper Bathonian in the Częstochowa region (Szczepanik et al., 2007; Dudek, 2012; Witkowska, 2012).

\section{CONCLUSIONS}

1. Berthierine is a green or yellow-brown clay mineral, the presence of which in Middle Jurassic sideritic siliciclastic rocks has been confirmed by XRD and SEM analyses. It comprises mostly ooids and also occurs less commonly in the cement of sideritic sandstones, conglomerates, coquinas and clayey siderites, and fills voids in bioclasts. Berthierine in ooids is characterized by $\mathrm{FeO}$ content of up to about $29 \mathrm{wt}$.\% in the northeastern margin of the Holy Cross Mountains, and up to approximately 38 wt.\% in the Częstochowa region. This may suggest a greater supply of iron from land to the Middle Jurassic (Bajocian) basin in the Częstochowa area compared with the northeastern margin of the Holy Cross Mountains.

2. Among the clay minerals, apart from berthierine, also illite, kaolinite and chlorites have been identified in the sideritic rocks. Variability in the composition of clay minerals within deposits of different ages in the Middle Jurassic could suggest changes in climatic conditions in both of the areas studied.

3. Berthierine ooids were observed mainly in sideritic sandstones, rarely in clayey siderites, and in a few samples of sideritic conglomerate and coquina. Their state of preservation var- ied. They underwent diagenetic processes of mechanical compaction, replacement and alteration. Berthierine was replaced by carbonate minerals and pyrite, and altered to kaolinite. Ooids, which are composed of the carbonate minerals sideroplesite, pistomesite, Fe-calcite and ankerite, and locally of pyrite and kaolinite, are common components of sideritic rocks. They are always secondary after berthierine ooids.

4. In the sideritic rocks, berthierine occurs primarily in those deposited in the shoreface and deltaic environments of the Early and Middle Bathonian of the northeastern margin of the Holy Cross Mountains, and of the Late Bajocian of both study areas. Berthierine ooids from the Bathonian sideritic rocks are characterized by a better degree of preservation compared to those from the Bajocian and Aalenian deposits. The effects of diagenetic processes are better developed in the marine sideritic sandstones, conglomerates and coquinas, deposited mostly in the shoreface zone, compared to those observed in deltaic deposits. The strongest effects of the processes of berthierine replacement and alteration have been found in clayey siderites deposited in a marine environment, including shoreface to offshore. In the Częstochowa region, the effects of diagenetic replacement and alteration processes are more poorly developed compared to those observed in the northeastern margin of the Holy Cross Mountains.

5. Berthierine was formed in the early diagenetic stage (eodiagenesis) in suboxic conditions where iron-bearing freshwater mixed with sea water probably at a temperature of about $25-45^{\circ} \mathrm{C}$. This mineral is chemically and structurally unstable, causing its transformation to chamosite as a result of recrystallisation process at a temperature of $70^{\circ} \mathrm{C}$. Berthierine may have been the precursor of ferruginous chlorites found in some samples. This may show that, during their diagenetic history, the rocks could locally attain temperatures $>60^{\circ} \mathrm{C}$, which is suggested by the results of analysis of fluid inclusions in some sideroplesite and pistomesite crystals, indicating the temperatures of their crystallisation to be $62-137^{\circ} \mathrm{C}$.

Acknowledgements. The authors are grateful to Reviewers A. García-Frank, P. Leonowicz and J. Powell for their suggestions and comments that greatly improved an earlier version of this manuscript. Professor T. Peryt, GQ Editor-in-Chief, is thanked for final editing of the manuscript. Special thanks are due to A. Feldman-Olszewska for allowing us to use the results of her unpublished sedimentological study. This paper is a part of the projects No. N N307 330339 financed by the Ministry of Science and Higher Education, and No. 61.2201.0604.00.0 of the Polish Geological Institute - National Research Institute. XRD analysis was performed by W. Narkiewicz, and the SEM examination by L. Giro and E. Starnawska.

\section{REFERENCES}

Aagard, P., Jahren, J.S., Harstad, A.O., Nilsen, O., Ramm, M., 2000. Formation of grain-coating chlorite in sandstones. Laboratory synthesize vs. natural occurrences. Clay Minerals, 35 : 261-269.

Brindley, G.W., Brown, G., 1984. Crystal Structures of Clay Minerals and Their X-ray Identification. Mineralogical Society, London.

Browne, G.H., Kingston, D.M., 1993. Early diagenetic spherulitic siderites from Pennsylvanian palaeosols in the Boss Point Formation, Maritime Canada. Sedimentology, 40: 467-474.
Choquette, P.W., Pray, L.C., 1970. Geologic nomenclature and classification of porosity in sedimentary carbonates. AAPG Bulletin, 54: 207-220.

Cieśla, E., 1958. Nowe dane o przebiegu północnej części antykliny inowłodzkiej (in Polish). Przegląd Geologiczny, 3: 144-145.

Claypool, G.E., Kaplan, I.R., 1974. The origin and distribution of methane in marine sediments. Marine Science, 3: 97-139. 
Daniec, J., 1963. The Dogger of the middle part of the northeastern surrounding cover of the Święty Krzy Mountains (in Polish with English summary). Biuletyn Instytutu Geologicznego, 168 37-86.

Daniec, J., 1970. Middle Jurassic (in Polish with English summary). Prace Instytutu Geologicznego, 56: 99-134.

Dreesen, R., 1989. Oolitic ironstones as event-stratigraphical marker beds within the Upper Devonian of the Ardeno-Rhenish Massif. Geological Society Special Publications, 46: 65-78.

Dudek, T., 2012. Clay minerals as palaeoenvironmental indicators in the Bathonian (Middle Jurassic) ore-bearing clays from Gnaszyn, Kraków-Silesia Homocline. Acta Geologica Polonica, 62 297-305.

Ehrenberg, S.N., 1993. Preservation of anomalously high porosity in deeply buried sandstones by grain-coating chlorite: examples from the Norwegian Continental Shelf. AAPG Bulletin, 77 $1260-1286$

Feldman-Olszewska, A., 1997. Depositional architecture of the Polish epicontinental Middle Jurassic basin. Geological Quarterly, 41 (4): 491-508.

Feldman-Olszewska, A., 1998. Palaeogeographical maps of Middle Jurassic, pl. 36-47. In: Palaeogeographical Atlas of the Epicontinental Permian and Mesozoic in Poland (eds. R Dadlez, S. Marek and J. Pokorski). Państwowy Instytut Geologiczny, Warszawa.

Flügel, E., 2010. Microfacies of Carbonate Rocks. Springer-Verlag, Berlin-Heidelberg.

Fritz, S.J., Toth, T.A., 1997. An Fe-berthierine from a Cretaceous laterite: part II. Estimation of Eh, ph and $\mathrm{pCO}_{2}$ conditions of formation. Clays and Clay Minerals, 45: 590-586.

García-Frank, A., Ureta, S., Mas, R., 2012. Iron-coated particles from condensed Aalenian-Bajocian deposits: evolutionary model (Iberian Basin, Spain). Journal of Sedimentary Research, 82: 953-968.

Gedl, P., Boczarowski, A., Dudek, T., Kaim, A., Kędzierski, M., Leonowicz, P., Smoleń, J., Szczepanik, P., Witkowska, M., Ziaja, J., 2006. Biostratigraphical framework from Bajocian to Oxfordian. Stop B1.7 - Gnaszyn Clay pit (Middle Bathonian-lowermost Upper Bathonian). Lithology, fossil assemblages and palaeoenvironment. In: Jurassic of Poland and Adjacent Slovakian Carpathians (eds. A. Wierzbowski, R. Aubrecht, J. Golonka, J. Gutowski, M. Krobicki, B.A. Matyja, G. Pieńkowski and A. Uchman): 155-156. Field Trip Guidebook. 7th International Congress on the Jurassic System, September 6-18, Kraków, Poland.

Gedl, P., Ziaja, J., 2012. Palynofacies from Bathonian (Middle Jurassic) ore-bearing clays at Gnaszyn, Kraków-Silesian Homocline, Poland, with special emphasis on sporomorph ecogroups. Acta Geologica Polonica, 62: 325-349.

Giles, M.R., de Boer, R.B., 1990. Origin and significance of redistributional secondary porosity. Marine and Petroleum Geology, 7: 378-397.

Hallam, A., 2001. A review of the broad pattern of Jurassic sea-leve changes and their possible causes in the light of current knowledge. Palaeogeography, Palaeoclimatology, Palaeoecology, 167: 23-37.

Hornibrook, E.R.C., Longstaffe, F.J., 1996. Berthierine from the Lower Cretaceous Clearwater Formation, Alberta, Canada. Clays and Clay Minerals, 44: 1-21.

lijima, A., Matsumoto, R., 1982. Berthierine and chamosite in coa measures of Japan. Clays and Clay Minerals, 30: 264-274.

Jahren, J.S., Aagaard, P., 1989. Compositional variations in diagenetic chlorites and illites and relationships with formation-water chemistry. Clay Minerals, 24: 157-170.

Jaskólski, S., 1928. Die oolitischen Toneisenerzlagerstätten der Gegend von Częstochowa (in Polish with German summary) Rocznik Polskiego Towarzystwa Geologicznego, 4: 1-91.

Jaworowski, K., 1987. Petrographic canon of the most common sedimentary rocks (in Polish). Przeglad Geologiczny, 35 205-209.
Kearsley, A.T., 1989. Iron-rich ooids, their mineralogy and microfabric: clues to their origin and evolution. Geological Society Special Publications, 46: 141-164.

Kimberley, M.M., 1994. Debate about ironstone: has solute supply been surficial weathering, hydrothermal convection, or exhalation of deep fluids? Terra Nova, 6: 116-132.

Knox, R.W.O'B., 1970. Chamosite ooliths from the Winter Gill ironstone (Jurassic) of Yorkshire, England. Journal of Sedimentary Petrology, 40: 1216-1225.

Kobyłecki, M., 1948. Jurassic clay iron ores of Tychów Belt between Rogów and Ćmielów (in Polish with English summary). Biuletyn Państwowego Instytutu Geologicznego, 41: 8-42.

Kopik, J., 1998. Lower and Middle Jurassic of the north-eastern margin of the Upper Silesian Coal Basin (in Polish with English summary). Prace Państwowego Instytutu Geologicznego, 378: 67-131.

Kopik, J., Marcinkiewicz, T., 1997. The Middle Jurassic. Biostratigraphy (in Polish with English summary). Prace Państwowego Instytutu Geologicznego, 153: 236-263.

Kozłowska, A., 2014. Diagenesis of the Middle Jurassic siderite rocks south of Tomaszów Mazowiecki (in Polish). Przewodnik wycieczek terenowych, abstrakty i artykuły, Jurassica XI, 50 .

Kozłowska, A., Feldman-Olszewska, A., Kuberska, M., Maliszewska, A., 2008. The Middle Jurassic siderites from the northern edge of the Holy Cross Mountains. Schriftenreihe der Deutschen Gesellschaft für Geowissenschaften, 58: 158.

Kozłowska, A., Feldman-Olszewska, A., Kuberska, M., Maliszewska, A., 2011. Sedimentary environments and diagenesis of the Middle Jurassic siderites in the North Margin of the Holy Cross Mountains, Poland. Abstracts, 28th IAS Meeting of Sedimentology, 5-8 July, Zaragossa, Spain, 522, Abstracts28thlAS.pdf

Kozłowska, A., Kuberska, M., Feldman-Olszewska, A., Jarmołowicz-Szulc, K., Maliszewska, A., 2013. The Middle Jurassic siderite iron ore deposits in Southern Poland. Acta Mineralogica Sinica, 33: 5.

Kuźniar, C., 1928. Les minerais de fer oolitique à Parczów, près d'Opoczno (in Polish with French summary). Sprawozdania Państwowego Instytutu Geologicznego, 4: 710-755.

Leonowicz, P., 2012. Sedimentology and ichnology of Bathonian (Middle Jurassic) ore-bearing clays at Gnaszyn, Kraków-Silesian Homocline, Poland. Acta Geologica Polonica, 62: 281-296.

Leonowicz, P., 2013. The significance of mudstone fabric combined with palaeoecological evidence in determining sedimentary processes - an example from the Middle Jurassic of southern Poland. Geological Quarterly, 57 (2): 243-260.

Longstaffe, F.J., Ayalon, A., 1987. Oxygen-isotope studies of clastic diagenesis in the Lower Cretaceous Viking Formation, Alberta: implication for the role of meteoric water. Geological Society Special Publications, 36: 277-296.

Lott, G., Wong, T., Dusar, M., Andsbjerg, J., Monnig, E., Feldman-Olszewska, A., Verreussel, R., 2010. Jurassic. In Petroleum Geological Atlas of the Southern Permian Basin Area (eds. H. Doornenbal and A. Stevenson): 173-193. EAGE Publications, Houten.

Maliszewska, A., Kozłowska, A., Kuberska, M., 2005. Mineralogy of Middle Jurassic siderites of the Kujawy region (Polish Lowlands) - preliminary results. Schriftenreihe der Deutschen Gesellschaft für Geowissenschaften, 38: 100

Maliszewska, A., Kozłowska, A., Kuberska, M., 2006. Origin of the Middle Jurassic siderite rocks from Central Poland. Volumina Jurassica, 4: 95-96.

Maliszewska, A., Kozłowska, A., Kuberska, M., 2007. Diagenesis of the Middle Jurassic sideritic rocks from Central and NW Poland (in Polish). Przegląd Geologiczny, 55: 297-298.

Marynowski, L., Zatoń, M., Simoneit, B.R.T., Otto, A., Jędrysek, M.O., Grelowski, C., Kurkiewicz, S., 2007. Compositions, sources and depositional environments of organic matter from the Middle Jurassic clays of Poland. Applied Geochemistry, 22: 2456-2485.

Meunier, A., 2005. Clays. Berlin, Springer. 
Morad, S., 1998. Carbonate cementation in sandstones: distribution patterns and geochemical evolution. IAS Special Publication, 26: 1-26.

Odin, G.S., 1988. The verdine facies from the lagoon of New Caledonia. Developments in Sedimentology, 45: 57-82.

Odin, G.S., 1990. Clay mineral formation at the continental-ocean boundary: the verdin facies. Clay Minerals, 25: 477-483.

Odin, G.S., Matter, A., 1981. De glauconarium origine. Sedimentology, 28: 611-641.

Odin, G.S., Knox R.W.O'B., Gygi, R.A., Guerrak, S., 1988. Green marine clays from the oolithic ironstone facies. Developments in Sedimentology, 45: 29-52.

Osborne, M., Haszeldine, R.S., Fallick, A.E., 1994. Variation in kaolinite morphology with growth temperature in isotopically mixed pore-fluids, Brent Group, UK North Sea. Clay Minerals, 29: $591-608$.

Passendorfer, E., 1927. Compte-rendu des recherches géologiques exécutées en 1926 pour la feuille Przedbórz (in Polish). Posiedzenia Naukowe Państwowego Instytutu Geologicznego, 16: 10-11.

Passendorfer, E., 1928. Compte-rendu des recherches géologiques exécutées en 1927 pour la feuille Opoczno (in Polish). Posiedzenia Naukowe Państwowego Instytutu Geologicznego, 19/20: 5-8.

Pieńkowski, G., Schudack, M.E. (co-ordinators), Bosák, P., Enay, R., Feldman-Olszewska, A., Golonka, J., Gutowski, J., Herngreen, G.F.W., Jordan, P., Krobicki, M., Lathuiliere, B., Leinfelder, R.R., Michalík, J., Mönnig, E., Noe-Nygaard, N., Pálfy, J., Pint, A., Rasser, M.W., Reisdorf, A.G., Schmid, D.U., Schweigert, G., Surlyk, F., Wetzel, A., Wong, T.E., 2008 Jurassic. In: The Geology of Central Europe. Volume 2: Mesozoic and Cenozoic (ed. T. McCann): 823-922. Geological Society of London.

Pufahl, P.K., Grimm, K.A., 2003. Coated phosphate grains: proxy for physical, chemical, and ecological changes in seawater. Geology, 31: 801-804.

Reolid, M., Abad, I., Martin-García, J.M., 2008. Paleoenvironmental implications of ferruginous deposits related to a Middle-Upper Jurassic discontinuity (Prebetic Zone, Betic Cordillera, Southern Spain). Sedimentary Geology, 203: 1-16.

Rivas-Sanchez, M.L., Alva-Valdivia, L.M., Arenas-Alatorre, J., Urrutia-Fucugauchi, J., 2006. Berthierine and chamosite hydrothermal: genetic guides un the Peńa Colorada magnetite-bearing ore deposit, Mexico. Earth Planets Space, 58: 1389-1400.

Ryan, P.C., Hillier, S., 2002. Berthierine/chamosite, corrensite, and discrete chlorite from evolved verdine and evaporate-associated facies in the Jurassic Sundance Formation, Wyoming. American Mineralogist, 87: 1607-1615.

Samsonowicz, J., 1932. Sur le tracé et le caractère de la limite entre le Jurassigue et le Crétacé sur le versant nord-est du Massif de Ste Croix (in Polish with French summary). Sprawozdania Państwowego Instytutu Geologicznego, 7: 208-226.

Sheldon, N.D., Retallack, G.J., 2002. Low oxygen levels in earliest Triassic soils. Geology, 30: 919-922.

Stoch, L., 1974. Minerały ilaste (in Polish). Wyd. Geol., Warszawa.
Sturesson, U., Heikoop, J.M., Risk, M.J., 2000. Modern and Paleozoic iron ooids; a similar volcanic origin. Sedimentary Geology, 136: 137-146.

Szczepanik, P., Witkowska, M., Sawłowicz, Z., 2007. Geochemistry of Middle Jurassic mudstones (Kraków-Częstochowa area, southern Poland): interpretation of the depositional redox conditions. Geological Quarterly, 51 (1): 57-66.

Taylor, K.G., 1990. Berthierine from the non-marine Wealden (Early Cretaceous) sediments of south-east England. Clay Minerals, 25: 391-399.

Taylor, K.G., 1998. Spatial and temporal variations in early diagenetic organic matter oxidation pathways in Lower Jurassic mudstones of eastern England. Chemical Geology, 145: 47-60.

Taylor, K.G., Curtis, C.D., 1995. Stability and facies association of early diagenetic mineral assemblages: an example from a Jurassic ironstone-mudstone succession, U.K. Journal of Sedimentary Research, A65: 358-368.

Taylor, K.G., Simo, T.J.A., Yocum, D., Leckie, D.A., 2002. Stratigraphic significance of ooidal ironstone from the Cretaceous western interior seaway: the Peace River Formation, Alberta, Canada, and the Castlegate Sandstone, Utah, U.S.A. Journal of Sedimentary Research, 72: 316-327.

Turnau-Morawska, M., 1961. Petrographic character of the ironstone of the Vesulian in the Łęczyca region (in Polish with English summary). Biuletyn Instytutu Geologicznego, 172: 5-69.

Velde, B., 1995. Compaction and diagenesis. In: Origin and Mineralogy of Clays: Clays and Environment (ed. B. Velde): 220-246. Springer-Verlag.

Wierzbowski, H., Joachimski, M., 2007. Reconstruction of late Bajocian - Bathonian marine palaeoenvironments using carbon and oxygen isotope ratios of calcareous fossils from the Polish Jura Chain (central Poland). Palaeogeography, Palaeoclimatology, Palaeoecology, 254: 523-540.

Wilson, M.J., 1987. X-ray powder diffraction methods. In: A Handbook of Determinative Methods in Clay Mineralogy (ed. M.J. Wilson): 26-98. Blackie, New York.

Wilson, M.J., 2013. Sheet silicicates: clay minerals. Rocks-forming minerals, 3C. The Geological Society, London.

Witkowska, M., 2012. Palaeoenvironmental significance of iron carbonate concretions from the Bathonian (Middle Jurassic) ore-bearing clays at Gnaszyn, Kraków-Silesian Homocline, Poland. Acta Geologica Polonica, 62: 307-324.

Worden, R.H., Morad, S., 2003. Clay minerals in sandstones: controls on formation, distribution ad evolution. IAS Special Publication, 34: 3-41.

Young, T.P., 1989. Eustatically controlled ooidal ironstone deposition: facies relationships of the Ordovician open-shelf ironstones of Western Europe. Geological Society Special Publications, 46: 51-63.

Young, T.P., Taylor, W.E.G., 1989. Phanerozoic ironstones. Geological Society Special Publications, 46.

Zatoń, M., Marynowski, L., Szczepanik, P., Bond, D.P.G., Wignall, P.B., 2009. Redox conditions during sedimentation of the Middle Jurassic (Upper Bajocian-Bathonian) clays of the Polish Jura (south-central Poland). Facies, 55: 103-114. 